\title{
Elevated carboxyhaemoglobin as a novel indicator for extracorporeal membrane haemolysis and oxygenator exchange
}

\author{
Kenneth R. Hoffman ${ }^{1,2^{*}}$, Aidan J. C. Burrell ${ }^{1,2}$, Arne Diehl ${ }^{1,2}$ and Warwick Butt 3,4,5
}

\section{Dear Editor,}

Plasma free haemoglobin is the gold standard for monitoring for intravascular haemolysis in extracorporeal membrane oxygenation (ECMO), and its use is recommended by the Extracorporeal Life Support Organisation [1]. Elevated plasma free haemoglobin is an independent predictor of mortality during ECMO [2]. Severe haemolysis may herald a hyperfibrinolytic state associated with bleeding, thrombosis and potential membrane oxygenator dysfunction. However, the routine use of plasma free haemoglobin has certain limitations: it is not universally available in all laboratories, it is prone to error due to traumatic sampling, spectrophotometric methods are susceptible to interference from bilirubin and lipaemia and it can take considerable time to perform.

Carboxyhaemoglobin is also used as a marker of intravascular haemolysis. Free haem is degraded by haem oxygenase into biliverdin, free iron and carbon monoxide. This is the primary source of endogenous carbon monoxide production. Several case reports have demonstrated dramatically elevated carboxyhaemoglobin in the setting of haemolysis on ECMO, with no reported cases surviving [3, 4]. There is also evidence of low-level elevation in almost half of veno-venous ECMO patients [5]. The use of carboxyhaemoglobin as a marker of haemolysis has several benefits. It is widely and rapidly available

\footnotetext{
*Correspondence: k.hoffman@alfred.org.au

${ }^{1}$ Intensive Care Unit, Alfred Hospital, Melbourne, VIC, Australia

Full list of author information is available at the end of the article
}

on routinely collected blood gases through co-oximetry, and it is not susceptible to elevation due to traumatic sampling.

In our centre, evidence of haemolysis frequently results in an ECMO circuit exchange. Circuit-driven haemolysis is generally interrupted, normalising the plasma free haemoglobin and preventing progression to a hyperfibrinolytic state or membrane oxygenator dysfunction.

To demonstrate the possible use of carboxyhaemoglobin as a marker of haemolysis on ECMO, we analysed the blood results of four patients on veno-venous ECMO for severe respiratory failure who had circuit exchanges due to suspected intravascular haemolysis with elevated plasma free haemoglobin. Plasma free haemoglobin and carboxyhaemoglobin data were collected for the $72 \mathrm{~h}$ before and after ECMO circuit exchange and are presented in Fig. 1.

The results demonstrate that carboxyhaemoglobin levels were elevated prior to the circuit exchange in all cases and correlated with acute rises in plasma free haemoglobin. In patients $1-3$, carboxyhaemoglobin levels then fell over the subsequent days post-circuit exchange. Patient 4 showed the same correlation, however died of suspected overwhelming sepsis with diffuse intravascular coagulation $30 \mathrm{~h}$ post-circuit exchange.

These preliminary results suggest carboxyhaemoglobin is potentially a novel marker of haemolysis on ECMO and may be useful as an indicator for ECMO circuit exchange. Further well-designed prospective studies are needed to investigate whether the relationship between carboxyhaemoglobin and intravascular haemolysis during ECMO is more widespread, and original author(s) and the source, provide a link to the Creative Commons licence, and indicate if changes were made. The images or other third party material in this article are included in the article's Creative Commons licence, unless indicated otherwise in a credit line to the material. If material is not included in the article's Creative Commons licence and your intended use is not permitted by statutory regulation or exceeds the permitted use, you will need to obtain permission directly from the copyright holder. To view a copy of this licence, visit http://creativecommons.org/licenses/by/4.0/. The Creative Commons Public Domain Dedication waiver (http://creativeco mmons.org/publicdomain/zero/1.0/) applies to the data made available in this article, unless otherwise stated in a credit line to the data. 


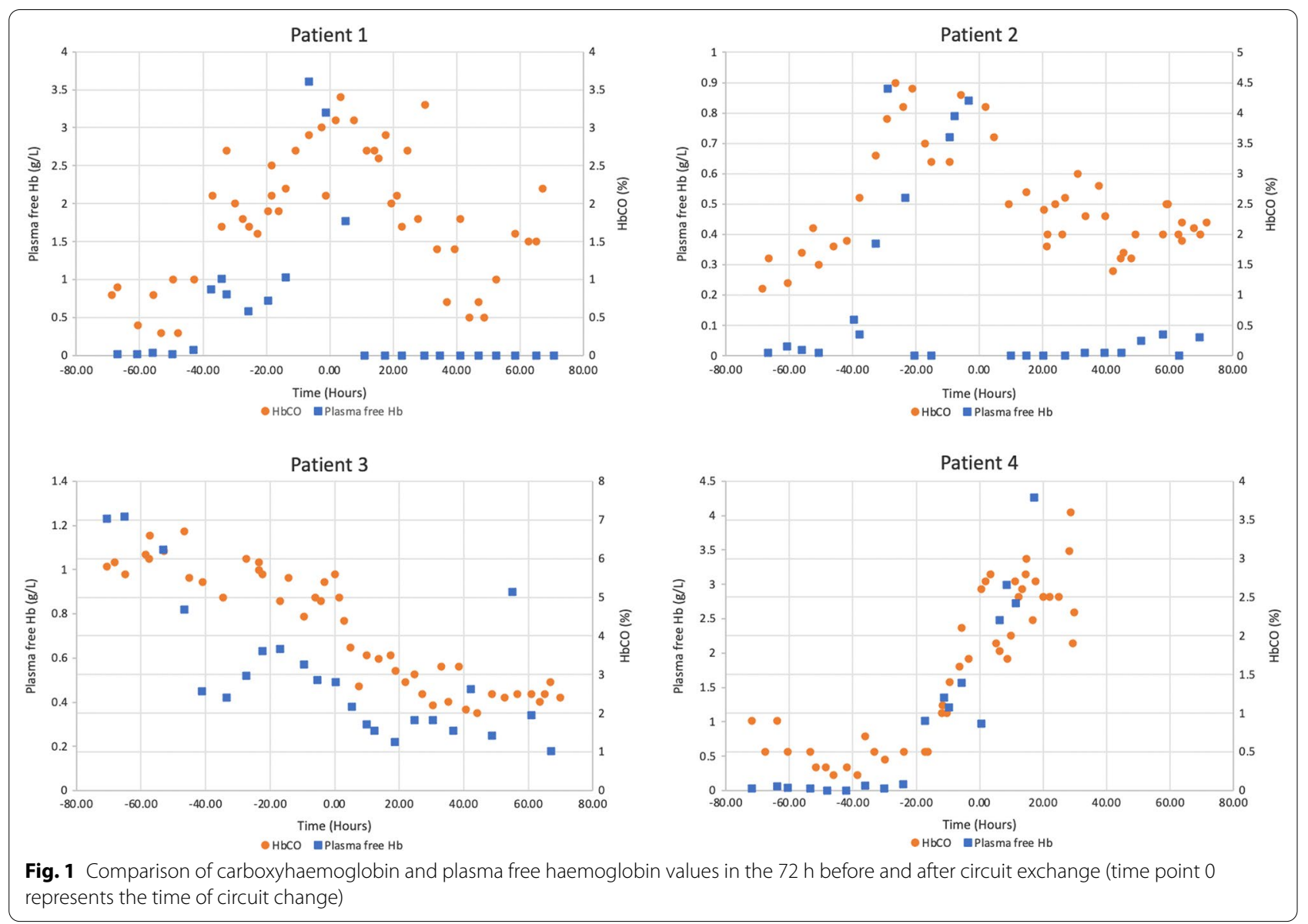

whether it has a clinically useful role in the management of ECMO patients.

\section{Authors' contributions}

All authors made substantial contributions to the work; the first draft was written by Kenneth R Hoffman, and all authors read and approved the final manuscript.

\section{Funding}

Not applicable.

\section{Availability of data and materials}

Original data are available on request.

\section{Code availability}

Not applicable.

\section{Declarations}

\section{Consent for publication}

The requirement to consent for publication was waived by the Alfred Hospital Ethics Committee due to the retrospective nature of the research, and deidentified data had no foreseeable physical, psychological, social, financial or cultural risks to participants and there was adequate protection of their privacy and confidentiality.

\section{Ethics approval}

Research ethics approval was granted by the Alfred Hospital Ethics Committee (Project 332/19)

\section{Competing interests}

No competing interests to declare.

\section{Author details}

${ }^{1}$ Intensive Care Unit, Alfred Hospital, Melbourne, VIC, Australia. ${ }^{2}$ Department of Epidemiology and Preventative Medicine, School of Public Health, Monash University, Melbourne, Australia. ${ }^{3}$ Intensive Care Unit, The Royal Children's Hospital, Melbourne, VIC, Australia. ${ }^{4}$ Faculty of Medicine Nursing and Health Sciences, Monash University, Melbourne, Australia. ${ }^{5}$ Paediatric Intensive Care, Murdoch Children's Research Institute, Melbourne, Australia.

Received: 14 April 2021 Accepted: 19 April 2021

Published online: 27 April 2021

\section{References}

1. Extracorporeal Life Support Organization (2017) ELSO Guidelines for Adult Respiratory Failure, Version 1.4. Extracorporeal Life Support Organization. https://www.elso.org/resources/guidelines.aspx. Accessed 23 Feb 2021.

2. Omar HR, Mirsaeidi M, Socias S, Sprenker C, Caldeira C, Camporesi EM, Mangar D. Plasma free hemoglobin is an independent predictor of 
mortality amoung patients on extracorporeal membrane oxygenation support. PLoS ONE. 2015;10(4):e0124034. https://doi.org/10.1371/journal. pone. 0124034

3. Burns J, Hurtado-Doce A, Lees NJ. Carboxyhemoglobin associated with hemolysis as a marker of impending oxygenator failure in VA ECMO. Crit Care Med. 2015:43(12 Suppl 1):38. https://doi.org/10.1097/01.ccm.00004 73974.89362.6e

4. Man KM, Ngai LK. Endogenous carbon monoxide production in extracorporeal membrane oxygenation-related hemolysis: potential use of point-of-care CO-oximetry carboxyhemoglobin to detect hemolysis. Clin Case Rep. 2018;6(2):346-9. https://doi.org/10.1002/ccr3.1351.
5. Shah N, Gibson C, Kitchen G, Hockstein M, Sokolovic M. 142: elevated carboxyhemoglobin levels in patients requiring extracorporeal membrane oxygenation. Crit Care Med. 2016;44(12):113. https://doi.org/10.1097/01. ccm.0000508824.16403.98.

\section{Publisher's Note}

Springer Nature remains neutral with regard to jurisdictional claims in published maps and institutional affiliations.
Ready to submit your research? Choose BMC and benefit from:

- fast, convenient online submission

- thorough peer review by experienced researchers in your field

- rapid publication on acceptance

- support for research data, including large and complex data types

- gold Open Access which fosters wider collaboration and increased citations

- maximum visibility for your research: over $100 \mathrm{M}$ website views per year

At BMC, research is always in progress.

Learn more biomedcentral.com/submissions 